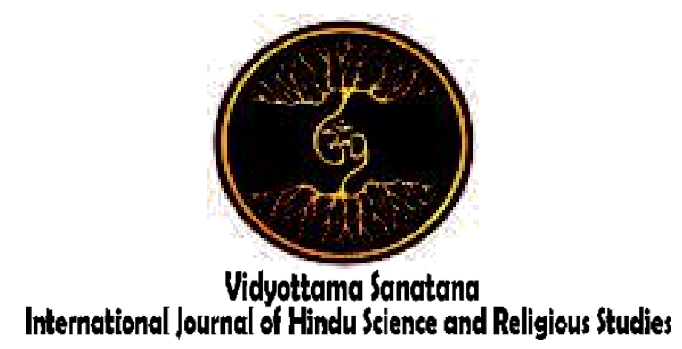

Vol. 3 No. 2 October 2019

\title{
THE UTILIZATION OF INSTRAGRAM AS THE MEDIA TO INCREASE RELIGIOUS BEHAVIOR FOR STUDENT
}

\author{
By:
}

Luh Kadek Dwi Utami, I Ketut Sudarsana, Ni Made Yuliani, I Nyoman Piartha

Institut Hindu Dharma Negeri Denpasar

E-mail : iketutsudarsana@ihdn.ac.id

\begin{abstract}
Nowadays, People religious behavior has decreased because of misusing information access on social media. It shows the bad influence caused by the existence of social media. However, social media can also be used as a medium to improve human's religious behavior. The use of instagram as one of the social media product as a tool (education technology) to improve students' religious behavior is done through the project method. The project method that applies the habituation model is done by students by always making a live story on Instagram about the activities they do before going to school, such as praying and saying farewell to parents in a certain period of time. Activities are carried out continuously that will form the character of students who always reflect the commendable behavior that is a form of religious behavior of a person.
\end{abstract}

Keywords: Instragram, Religious, Student

\section{INTRODUCTION}

Social media is often likened to a double-edged knife which now has a rapid increase user. Nowadays, social media users are not only adults but also teenagers even elementary school children have their own social media accounts. This opinion is supported by UNESCO data which states that the number of Indonesians who upload new contents like tweet, photo, and ect on social media is very high, reaching 28,000 tweets per minute.
The high rate access of Indonesian to social media is a result of the availability of internet networks, which makes the public stunned and addict on social media. The statement is in line with the opinion of the Director General of Information and Public Communication (Kominfo), R. Niken Widiastuti at the opening of the Trust Media Summit 2018 in Jakarta which revealed that currently more than $53 \%$ of the Indonesia people are connected to the internet. The activeness of the Indonesian society in the 
world of social media should be able to strengthen democracy and increase social care for others. However, in reality social media is often misused by many irresponsible individuals through the distribution of pornographic, blasphemous, slanderous and hateful content on behalf of certain groups, tribes, religions and groups and hoax information that can lead to a decrease of a person morality.

Decreasing morality is known as moral dissonance that is the inhibition of the values, norms and morals internalization process derived from a person's vibration. This point of view is supported by Otib (2014) who argued that moral dissonance is an echo or vibration in someone who inhibits the entry and internationalization process of education and values, norms and morals knowledge that exist in a person. Moral dissonance that caused by information accessed in social media bring the result in the decrease of human religious behavior. This is one of negative impact of social media.

However, on the other hand, social media can also be an educational technology that can improve human's religious behavior. This is based on the method of increasing religious behavior through project methods that aim to form a tendency (disposition) related to habituation. Habituation is a method that can shape good and laudable qualities in a person. In applying this method, social media functioned as a tool to improve human's religious behavior. One of the social media that can be used in the process of increasing religious behavior is Instagram.

Instagram is a social media that has features that make it easier for someone to share information about themselves in the form of photos, videos and live broadcast videos. These features help educators to monitor and observe what learners are doing during projects. In addition, these features can avoid students' dishonesty when working on a given project because educators can control it through live broadcasts by their students. Based on that statement, the author recommended Instagram as an educational technology that can be utilized by educators in shaping and improve students religious behavior.

\section{RESULT AND DISCUSSION}

Religious behavior is human behavior that is carried out based on the teachings of the religion human adheres to. This point of view is in line with the opinion of Jalaluddin who argues that religious behavior is an impulse found in a person to behave accordance with religious teachings. It is also supported by Ramayulis's response, which is all forms of activities in human life which in the implementation of religious values that are believed. Meanwhile, Abdul Aziz Ahyadi who views that religious behavior is a term or expression of life that can be measure, calculate and study embodied in the form of words, deeds or actions called the experience of Islamic teachings.

Referring to religion definitions above, a person's religious behavior can be measured by several dimensions which are part of religious behavior. The dimensions reviewed by Jalaluddin Rahmat suggest that there are five dimensions related to religious ideology and behavior. There are ideological dimension, religious practice dimension, dimension of appreciation (experiential), dimension of religious knowledge (intellectual). The definition of the religious dimensions by Jalaluddin is as follows:

a. The ideological dimension

b. The ideological dimension is human belief of religious values in the dogmatic adherents.

c. The dimensions of religious experience (Reveal)

d. The motivation occurs in person to behave in social life as a result of human religious teachings.

e. Dimension of appreciation (experimental)

f. A person's ability to experience and feel the sensation about religious experiences

g. The dimensions of religious knowledge (intellectual) 
h. The knowledge and learning level about the religion teachings especially about the main religion teachings.

i. Dimension of involvement (ritualistic).

The level of human in doing ritual activities that provide by religion. It can be the human involvement in ritual or other religious activities.

Those five dimensions bring the different religious behavior to every person who is also influenced by several factors. The factors that influence the formation of religious behavior based on the opinion of Azwar, namely:

a. Personal experience (human experience which involves deep emotional factors so that the experience is very strong imprints and gives an impression to human and it happens repeatedly which then makes strong attitude and behavior response);

b. A person who are considered as the important person (a person who are expected to approve someone's behavior and opinions or in other word is people who do not want to be disappointed and that have special meaning for that person);

c. Educational and religious institutions (where ethical, moral and spiritual values are developed and applied in daily life); and

d. Culture (the style and color of behavior that characterizes the place where a person is raised).

Based on the above opinion, the religious behavior of a person is influenced by four things which of these four factors, the educational and religious institutions become a system that has a great influence in instilling an understanding of the ethical, moral and spiritual values needed and applied in daily life and prepared daily life necessary in the future.

Education becomes an institution that is responsible for the formation of human religious behavior. In an attempt to shape human religious behavior, educational institutions used some methods to develop religious behavior. The method of developing religious behavior consists : 1) the method of telling stories is a method that uses stories as a medium in providing student's understanding to cultural, social and religious values, instilling work ethic, time ethic and natural ethos, that can help children to develop fantasy, cognitive and language dimensions within them); 2) the method of conversation and questioning is one of the learning methods used to stimulate the children courage and speaking ability);3) the method of assignment is a duty or assignment deliberately given to the child and must be finished by the child well); 4) method of field trip; 5) method of demonstration giving learning experiences through the act of seeing and listening followed by imitating the work that was demonstrated with the aim of providing a better learning experience so that children can get a good model from the demonstration and imitate it); 6) sociodrama method and role playing defines it as an activity to play a role in a story or dramatization of behavior ways in everyday social life that aims to improve children's understanding of the other perspectives); 7) the experimental method tells that experiment is an activity in which experiments are conducted by observing the process and the results of the experiment); and 8) the method of the project is a dynamic and flexible learning method that helps children understand various knowledge logically, concretely and actively).

Instagram is one of social media product that has various features that make user easier to share information in form of photos, videos or live broadcast [2]. The features contained in the instagram are: 1) Home Page (main page that displays (timeline) new photos of fellow users who have been followed); 2) Comments (as the Instagram social networking service provides commenting feature. Instagram photos can be commented in comment field); 3) Explore (display of popular photos that most Instagram users like); 4) Profile (user profile can know in detail about user information, the profile information can be seen by instagram user or the other user); 5) 
News Feed (a feature that displays notifications on various activities carried out by Instagram users); and 6) Insta Story (the latest feature in instagram that can be used to share user stories in the form of photos and videos that can be changed to be more interesting with the addition of other features and live broadcasts that can be shared with people who have followed someone's account, so that others can join the live broadcast by adding comments in the comments field that has been provided).

The project method using instagram as the media to improve human religious behavior can be done through these following stages.

a. Preparation / beginning

In this phase, educator conducts a review of students' understanding of religious behavior which should always be done. During the review process, educator can outline the understanding of the entire child involved in the project. In this phase, educator also establishes project that will be carried out by students. In this case, educators can assign their students to do live streaming (live streaming of content in the form of video or audio by using internet) of activities that does before leaving for school. These activities certainly reflect human religious behavior, such as praying and saying farewell word to parent. The project is carried out by students within a certain period that determined by educators.

b. The process of implementing project learning

In this phase, students doing every day activities that show their religious behavior through live broadcasts. This activity should be doing every day until the deadline has been set by the assigning teacher. In the initial phase of this project, students who were not accustomed to performing religious behavior such as praying and saying religious farewell word (kissing hand) to their parent and it would be forced to do so. This is because these activities are projects that he must complete within a predetermined period of time and must be done every day by using instagram as the media to do live broadcast so that the teacher can be watched it directly.

c. Taking conclusions / assessment

In this phase, educators carry out their functions as supervision and controllers who always observe and evaluate their students who have or are doing a given project. In this case, educators also carry out their duties to observe what their students are doing while working on the project carefully.

Student's activities that are share through live story and broadcast on instagram account they have every day up to the time specified by the teacher is one of character learning model, namely habituation. Habituation is something that is done repeatedly so that something can become a habit [7]. Habits that are carried out such activities above belong to habituation activities program. Programmatic habituation according to Mulyasa is an activity undertaken in learning with special planning in a certain period of time to develop learner's character individually, group and or classical. Furthermore, by using this model of habituation can generate internalization of values quickly. So that learners' behavior always reflects praiseworthy, disciplined, active learning, hard work, sincere, honest and responsible behaviors. Those behaviors show good religious behavior in accordance with the five dimensions as mentioned above.

\section{CONCLUSION}

Religious behavior is any form of human behavior in form of thoughts, words or deeds that are in accordance with the teachings of the religion people adheres to. Religious behavior can be measured through several dimensions, namely ideology, dimension of religious practice (consequential), dimension of appreciation (experential), dimension of religious knowledge (intellectual) and dimension of worship. Through those dimensions causes differences in religious behavior. Differences 
religious behavior is caused by several factors that are educational and religious institution.

Educational institution is the factor in the formation of religious behaviour. It can be work by applying several approaches such as storytelling method, conversation method and question and answer, assignment method, field trip method, demonstration method, socio drama and role playing method, and the last is project method. One of the most effective, efficient and transparent method that can be used by educators in religious behavior formation is project method approach. The project method is a method of approach in developing the religious behavior of the child through the activities of studying, recording, making, observing, investigating, reviewing, collecting and concluding. The implementation of this project method uses Instagram as one of the social media that makes users easier to share information through photos, videos or live story or broadcast activities they do. The project method requires specific time set by the teacher to their students to make live streaming on instagram when learners doing some activities before going to school, such as praying and kissing the hands of parents as a form of respect and asking for permission before leaving for school.

The activities are carried out over a period of time in order to form the behavior becomes a habit of learners. If the behavior has become a habit, then if students do not do the activity, they will feel something is missing or will feel uncomfortable. This is a form of students increasing religious behavior. In addition, by using the instragram live story, students cannot perform cheating or dishonesty in completing assigned projects. It shows that through live story project method, students can form an honest character, discipline, responsible and cooperate as well as to appeal to parents as the realization of God in real life.

\section{REFERENCES}

Ahyadi, A. A. (1998). Psikologi Agama Kepribadian Muslim Pancasila. Jakarta: Sinar Baru Algesindo.

Atmoko, D. B. (2012). Instagram Handbook Tips Fotografi Ponsel. Jakarta: Media Kita

Azwar, A. (2002). Pengantar Epidemiologi Edisi Revisi. Jakarta Barat : Binarupa Aksara.

Gunarti, W. (2017). Metode Pengembangan Perilaku dan Kemampuan Dasar Anak Usia Dini. Tanggerang Selatan: Universitas Terbuka.

Hidayat, O. S. (2014). Metode Pengembangan Moral \& Nilai-nilai Agama. Tanggerang Selatan: Universitas Terbuka.

Jalaluddin. (2012). Psikologi Agama. Jakarta: Rajawali Pers.

Mulyasa, H. E. (2016). Manajemen Pendidikan Karakter. Jakarta: Bumi Aksara.

Musfiroh, T. (2017). Materi Pokok Pengembangan Kecerdasan Majemuk. Tanggerang Selatan: Universitas Terbuka.

Nugraha, A. (2015). Materi Pokok Kurikulum dan Bahan Belajar TK. Tanggerang Selatan: Universitas Terbuka.

Prawiradilaga, D. S. (2012). Wawasan Teknologi Pendidikan. Jakarta: Kencana Prenada Media Group.

Ramayulis. (2007). Psikologi Agama. Jakarta: Kalam Mulia.

Rahman, U. (2009). Karakteristik Perkembangan Anak Usia Dini. Lentera Pendidikan. Vol 12 No. 1: 46-57

Sabara. (2012). "Geliat Syiah, Perubahan Paham dan Perilaku Keagamaan Mahasiswa Muslim di Makassar". Harmoni Jurnal Multikultural dan Multireligius. 46-55. 